\begin{tabular}{|l|l|l||}
\hline \multicolumn{2}{|c|}{ PublisherInfo } \\
\hline \hline PublisherName & $:$ & BioMed Central \\
\hline \hline PublisherLocation & $:$ & London \\
\hline \hline PublisherImprintName & $:$ & BioMed Central \\
\hline \hline
\end{tabular}

\title{
Associate Professor of Medicine
}

\begin{tabular}{|l|l|l||}
\hline \multicolumn{2}{|c||}{ ArticleInfo } \\
\hline \hline ArticleID & $:$ & 144 \\
\hline \hline ArticleDOI & $:$ & $10.1186 /$ ar-2000-66852 \\
\hline \hline ArticleCitationID & $:$ & 66852 \\
\hline \hline ArticleSequenceNumber & $:$ & 101 \\
\hline \hline ArticleCategory & $:$ & Paper Report \\
\hline ArticleFirstPage & $:$ & 1 \\
\hline ArticleLastPage & $:$ & 1 \\
\hline \hline & & RegistrationDate : 2000-10-4 \\
\hline ArticleHistory & $:$ & OnlineDate \\
\hline \hline ArticleCopyright & $:$ & Current Science Ltd2000-4 \\
\hline \hline ArticleGrants & $:$ & \\
\hline \hline ArticleContext & $:$ & 130753311 \\
\hline \hline
\end{tabular}


Richard Brasington, ${ }^{\text {Aff1 }}$

Affl Washington University School of Medicine, St Louis, Missouri, USA

\section{Keywords}

Collagen Induced Arthritis, complement regulatory proteins, gene therapy

\section{Context}

The complement system plays an important role in the pathogenesis of rheumatoid arthritis (RA). Soluble complement receptor 1 (sCR1) regulates complement activity, and may be useful as a therapeutic agent. This study tests the hypothesis that delivery of genes encoding truncated sCR1 (tsCR1) is an effective treatment for collagen-induced arthritis (CIA), a murine model for RA.

\section{Significant findings}

DBA/1 mice immunized with bovine type II collagen, then injected with syngeneic, immortalized fibroblasts transduced with tsCR1, developed less severe CIA and had less abnormal histological scores than control mice. The authors conclude that gene therapy with tsCR1 is a feasible therapy for CIA.

\section{Comments}

This work expands gene therapy for CIA to include the complement regulatory protein CR1, and focuses attention on the role of complement inhibition in the treatment of RA. Future efforts to apply such treaments to humans with RA may be beneficial. Whether complement inhibition will have the same pivotal effect as antagonism of tumor necrosis factor- $\hat{I}^{2}$ and IL-1 remains to be seen, and infectious complications are a concern.

\section{Methods}


Gene therapy via injection of transduced immortalized fibroblasts

\section{References}

1. Dreja H, Annenkov A, Chernajovsky Y: Soluble complement receptor 1 (CD 35) delivered by retrovirally infected syngeneic cells or by naked DNA injection prevents the progression of collageninduced arthritis. Arthritis Rheum. 2000, 43: 1698-1709.

This PDF file was created after publication. 